\title{
A Strategy for Sustainable Development of Cooperatives in Developing Countries: The Success and Failure Case of Agricultural Cooperatives in Musambira Sector, Rwanda
}

\author{
Sunghye Moon ${ }^{1}\left(\mathbb{D}\right.$ and Sang-ho Lee ${ }^{2, *}$ \\ 1 Department of Food and Resource Economics, Yeungnam University Graduate School, \\ Gyeongsan 38541, Korea; darpana@yu.ac.kr \\ 2 Department of Food Economics and Service, Yeungnam University, Gyeongsan 38541, Korea \\ * Correspondence: ecolee@yu.ac.kr
}

Received: 28 August 2020; Accepted: 15 October 2020; Published: 18 October 2020

\begin{abstract}
Many international aid agencies have been trying to utilize cooperatives as a strategic means for poverty reduction and rural community development in developing countries due to their characteristics, operational efficiency, and effectiveness. However, it is difficult to find a successful case due to various factors. This study tries to propose strategies that the aid agencies and local residents should use for the success of cooperatives in developing countries through an analysis of the success and failure cases of the two cooperatives established under the Saemaul ODA Program in Rwanda. While the length of the ODA program and scale of support significantly affect the cooperatives' self-reliance, what support they receive from the aid agencies and whether it is a long-term support plan considering exit strategies are also important factors of their success. In addition to the support of the aid agencies, efforts of the cooperative members are essential. Cooperatives should reinforce their sense of ownership to achieve the long-term goals of self-reliance and sustainability by setting clear and feasible short-term goals and achieving them one by one through cooperation among members, as in the case of Korea's Saemaul Undong.
\end{abstract}

Keywords: global saemaul ODA; cooperatives; sustainability; aid effectiveness; ownership; accountability

\section{Introduction}

The paradigm shift from Millennium Development Goals (MDGs) to Sustainable Development Goals (SDGs) urges the strengthening of the ownership of developing countries; global partnership for effective development cooperation; participation of more diverse entities of the public, civil society, and the private sector; and sustainability of social, economic, and environmental development. In this paradigm shift, social enterprises and cooperatives, and public-private partnerships have been recognized as effective and efficient tools to contribute to the achievement of SDGs in terms of ensuring development effectiveness of aid and sustainability of local economic growth.

Cooperatives, inter alia, can play various roles in rural community development as an independent and authorized economic business model consisting of community members at the local, regional, national, and international level. This has led aid agencies to attempt to utilize cooperatives as a means of poverty reduction and economic development. In the case of Rwanda, the "Cooperative Movement" has been pushed forward under the initiative of the government, which has tried to eradicate poverty and promote economic growth by developing cooperatives. In line with "Rwanda's development policy", the Rwanda Global Saemaul Undong (SMU) Program (Rwanda SMU program), which has been implemented in four villages in Rwanda aiming at rural development since 2010 with 
the South Korean government's funding, considered cooperatives as a tool for implementing the income generation project. In Gihogwe, which was one of the target villages of the Rwanda SMU program, two cooperatives-Gihogwe Rice Producers' Cooperative (rice cooperative) and Gihogwe Banana Producers' Cooperative (banana cooperative)—-were organized and obtained legal personality from the Rwandan government and delivered good performance with the support of the aid agency during the program period. However, the situation changed after the official assistance from the aid agency ended in 2016. The banana cooperative was almost on the verge of collapse, while the rice cooperative expanded its scale. The decisive and apparent cause of the banana cooperative's collapse was the default on the loan after the end of the SMU Official Development Assistance (ODA) program. However, it is necessary to see why the banana cooperative took out loans and why they failed to repay them. What were the reasons that the two agricultural cooperatives-which were established by ODA to mainly secure the sustainability of the project—ended up with totally different results? Identifying the cause of failure and turning it into an opportunity for development by taking lessons from it are essential to increase the aid effectiveness. Under this background, the study examined the success and failure factors of the two agricultural cooperatives and sought ways to enhance the effectiveness and sustainability of ODA projects using cooperatives.

This paper consists of five chapters, including an introduction and a conclusion. In Section 2, the necessity and methodology of this research are presented, and in Section 3, the success and failure of the agricultural cooperatives in Gihogwe village, the subject of this study, are analyzed in detail. In the Section 4 discussion, the cause of the banana cooperative failure is examined in terms of the absence of social and open innovation, and entire study is concluded in Section 5, presenting the strategies and efforts that the aid agencies and the cooperatives should undertake for the sustainable development of the cooperatives based on the above research results and discussion.

\section{Materials and Methods}

\subsection{Literature Review}

Cooperative, as a form of social economy model, can be viewed as the result of social innovation aimed at meeting social needs and achieving systemic change [1]. Unlike investor-owned firms (IOFs), cooperatives are "people-centered enterprises owned, controlled, and operated by and for their members" to fulfill their common economic, social, and cultural needs and seek to build a better community and world through cooperation [2]. Cooperatives, which are value-based and principle driven organizations, naturally have participatory and sustainable properties [3]. Especially because cooperatives place emphasis on the interest and welfare of their members and the co-prosperity of community, they are quicker than national, regional, and international organizations to recognize and identify local issues and needs, obtain the responses and consent of the locals, and access community resources with ease.

The United Nations has formally recognized the important role that cooperatives play in inclusive local community development by promoting people to participate in economic and social activities [4], and the International Labor Organization (ILO) highlighted the important role of cooperatives in the realization of SDGs, including their work to: "(1) end poverty, (2) empower girls and women and achieve gender equality, (3) provide quality education and lifelong learning, (4) ensure healthy lives, (5) ensure food security and good nutrition, (6) achieve universal access to water and sanitation, (7) secure sustainable energy, (8) create jobs, sustainable livelihoods, and equitable growth, (9) manage natural resource assets sustainably, (10) ensure good governance and effective institutions, (11) ensure stable and peaceful societies, (12) create a global enabling environment and catalyze long-term finance" [3].

In particular, agricultural cooperatives are considered key to poverty and hunger reduction. The Food and Agriculture Organization (FAO), International Fund for Agricultural Development (IFAD), and World Food Programme (WFP) emphasized that smallholder farmers could gain benefits 
such as bargaining power in purchasing inputs or product sales, resource sharing, and securing farmers' rights from agricultural cooperatives [5].

These positive impacts of cooperatives on social and economic development can be observed when they function well in line with the purpose of their establishment, such as building capacity of members, profit-making, providing members with services, and reinvesting in cooperative business through capital accumulation. In other words, when cooperatives achieve their own sustainable development, they can contribute to the sustainable development of local communities and further to the global sustainable development. Regarding sustainable development of cooperatives, Marziana et al. (2015) presented the sustainability indicators of cooperatives from the four environmental, social, economic, and governance and integrity aspects, and stated that cooperatives could secure sustainability by setting targets and indicators in line with the ultimate goal of cooperatives, using them as a guide for operation, and evaluating their performance according to indicators [6].

However, many cooperatives in developing countries have been facing challenges such as unfavorable institutional environments, lack of financial support, poor management, and limitations on market access [7]. These challenges may become more difficult to overcome for the agricultural cooperatives organized by smallholder farmers characterized by low level of education, limitations on information and market access, insufficient management skills, lack of funds, and low agricultural productivity [8]. Furthermore, fledgling cooperatives have a tendency to be undercapitalized, because the source of initial equity capital is mostly its members [9].

The study "Factors for successful development of farmer cooperatives in Northwest China" revealed that the key factors for the success of farmers' cooperatives are the following: a stable legal framework, leadership and active participation of farmers, financial and technical support from the government, and proper external support from professional non-governmental organizations (NGOs) [10]. Although Braverman (1991) was concerned about cooperatives being operated by external actors, he noted that they need support from the government and donors in the initial stage. When it comes to supporting cooperative units, it is said that the donors should focus on enhancing their managerial, technical, and decision-making capabilities, and that financial support is also necessary [11].

Rasiah (2019) presented the significance of open innovation for sustainable development [12]. Open innovation is an innovation process that creates additional value through the utilization of internal and external knowledge through an open system; thus, it can be viewed as a set of practices aiming to profit from innovation [13]. Referring to the case of poor farmers in Korea, Taiwan, Chile, and Malaysia in the past achieved rural and agricultural development through innovation that actively adopts foreign sources of knowledge, the evolution of scientific and technical information (STI) infrastructure, institutional innovation, and education, he emphasized that the participatory open innovation system has contributed to rural development [12]. This can also be applied to the development of cooperatives, and the inflow of external knowledge and resources can be taken as a process for innovation and an opportunity to create added value.

At a time when cooperatives are drawing attention as an effective means to the realization of SDGs and many aid agencies are moving to utilize cooperatives for rural development, it is necessary to consider and study what role the aid agencies and cooperatives should take, and what kind of support the aid agencies should provide for the sustainable development of cooperatives.

\subsection{Research Methodology}

This study aims to suggest the efforts that cooperatives and aid agencies should make to produce effective results and ensure sustainability based on the case studies of success and failure of two agricultural cooperatives established through ODA. Case studies are widely used in social science research. There is criticism that it is difficult to generalize the case analysis results, because studies on certain phenomena are mostly descriptive, based on their own experience, and provide limited validity [14]. However, a case study can be extremely useful in research for a deep and multidirectional understanding of complex issues [15]. 
The subjects of the case study were the rice cooperative and banana cooperative established in Gihogwe Village in Rwanda. The study focused on the details of support from donors and the process of success and failure based on the data collected by the author and secondary data such as project reports, research, and press releases. The author, Sunghye Moon, was dispatched to Gihogwe village by the aid agency as personnel for managing the village projects of the Rwanda SMU Program in July 2014 and stayed there for 14 months. She planned and implemented the "improved banana plantation project (banana project)" with the residents. This way, she could observe the banana and rice cooperatives from close range. The case study on the rice farming project and banana project were conducted mainly based on the data collected by herself as a project participant during her stay in Gihogwe village. The data about events that have occurred at the Banana cooperative from the last year of the SMU program until its end were obtained in December 2018 by interviewing a local staff member who worked as an agronomist for the banana project, a resident who was the chairperson of the cooperative, and four members of the cooperative.

This paper first gives a brief account of the cooperative movement in Rwanda and the internal limitations of the cooperatives there. Subsequently, the two agricultural cooperatives established by the SMU program in Gihogwe village are discussed in detail. The entire process from the establishment to the collapse of the banana cooperative is carefully examined to analyze the causes of failure from the perspectives of the board of directors and members of the cooperative. Further, the factors that affected the growth of the rice cooperative and failure of the banana cooperative are identified by comparative analysis of the establishment background, operation, and support received from the aid agencies of the two cooperatives. Consequently, this study proposes the roles and strategies that the aid agencies and cooperative members should take in the process of establishing and stabilizing the cooperatives to improve the effectiveness and sustainability of aid.

\subsection{Cooperative Movement in Rwanda}

The Republic of Rwanda, located in Central Africa, is one of the smallest countries, with a population of around 12.3 million. Rural population accounts for $82.79 \%$ of the total population. Rwanda is classified as a least-developed country, with per capita GNI (atlas method) estimated at USD 780 in 2018, and 55.5\% of the population lives with less than 1.9 dollars a day [16]. Rwanda, a landlocked country, has few natural resources, and the economy is based mostly on agriculture. An estimated $81 \%$ of the population are employed in the agricultural sector, and agriculture constituted an estimated $29 \%$ of GDP in 2018 [16]. Constraints on economic growth such as landlocked narrow territory, scarce natural resources, poor foundation of industry, high poverty rate, and high economic dependence on agriculture can be understood as the background in which the Rwanda government defines the cooperative movement as a means to eradicate poverty and promote economic growth. Although there was a negative view of cooperatives as a means to convey the government's policies, the Rwandan government enacted the "Cooperative Ordinance" in 1949 to foster cooperatives and promoted the cooperative movement, and Rwanda achieved quantitative growth of cooperatives, overcoming the tragedy of 1994 genocide [17]. After the Rwandan government set up the "Taskforce on Cooperative Promotion" to foster the environment for the development of cooperatives in 2005, the first Rwanda National Cooperatives Policy was set in 2006, which states the role of cooperatives across economic and social sectors.

The number of cooperatives substantially increased from 919 in 2005 to 8995 in March 2018 with $3,816,591$ registered members, which means that $55.3 \%$ of Rwanda's population over the age of 16 are members of cooperatives. Further, the number of non-financial cooperatives registered reached 8391 in 2018, increased by 3.24 times from 2010, steadily increasing every year. In addition, the share capital of cooperatives reached approximately 29.6 billion RWF (equivalent to around 34 million USD; calculated based on exchange rate provided by Exchange-Rate.org on 1 March 2018. 1 USD = 863.04475RWF) in March 2018, a 5.7-fold increase from 2010 [18]. 
Although there has been quantitative growth, capital accumulation and internal stability of cooperatives still need to be improved for the progress of the Rwandan cooperative movement. For instance, as shown in Table 1, agricultural cooperatives account for $29 \%$ of the registered non-financial cooperatives and $53 \%$ of the total number of members; however, the share capital is low compared to the other cooperatives.

Table 1. Distribution of cooperatives according to economic activity at national level.

\begin{tabular}{|c|c|c|c|c|c|c|c|c|c|}
\hline \multicolumn{10}{|c|}{ (Unit: No., \%, No., \%, No., \%, Rwf, Rwf) } \\
\hline \multirow{2}{*}{$\begin{array}{c}\text { Economic } \\
\text { Activity }\end{array}$} & \multirow{2}{*}{$\begin{array}{l}\text { No. of } \\
\text { Coops. }\end{array}$} & \multirow{2}{*}{ Ratio } & \multicolumn{5}{|c|}{ Membership } & \multirow{2}{*}{$\begin{array}{c}\text { Share } \\
\text { Capital (b) }\end{array}$} & \multirow{2}{*}{$\mathbf{b} / \mathbf{a}$} \\
\hline & & & Male & $\%$ & Female & $\%$ & Total(a) & & \\
\hline Agriculture & 2433 & 29 & 179,510 & 60 & 118,486 & 40 & 297,996 & $4,878,087,148$ & 16,370 \\
\hline Livestock & 1652 & 19.7 & 46,834 & 51 & 44,923 & 49 & 91,757 & $3,991,748,925$ & 43,503 \\
\hline Trading & 1207 & 14.4 & 29,507 & 53 & 26,609 & 47 & 56,116 & $8,310,857,882$ & 148,101 \\
\hline Service & 908 & 10.8 & 23,077 & 63 & 13,534 & 37 & 36,611 & $2,010,426,884$ & 54,913 \\
\hline Transport & 542 & 6.5 & 21,912 & 89 & 2,731 & 11 & 24,643 & $1,764,398,500$ & 71,598 \\
\hline Handicraft & 979 & 11.7 & 14,113 & 47 & 16,179 & 53 & 30,292 & $1,894,282,580$ & 62,534 \\
\hline Transformation & 98 & 1.2 & 3920 & 60 & 2648 & 40 & 6568 & $745,505,500$ & 113,506 \\
\hline Mining & 121 & 1.4 & 1971 & 80 & 500 & 20 & 2471 & $602,422,000$ & 243,797 \\
\hline Fishing & 94 & 1.1 & 3540 & 77 & 1080 & 23 & 4620 & $162,422,000$ & 35,156 \\
\hline Housing & 160 & 1.9 & 4930 & 71 & 2053 & 29 & 6983 & $4,803,614,000$ & 687,901 \\
\hline Other & 198 & 2.4 & 5096 & 63 & 3047 & 37 & 8143 & $498,431,800$ & 61,210 \\
\hline Sub Total & 8391 & 100 & 334,410 & 59 & 231,790 & 41 & 566,200 & $29,662,021,319$ & 52,388 \\
\hline
\end{tabular}

The SWOT analysis conducted by RCA (Table 2) pointed out the lack of members' sense of ownership, diligence, and self-help; limits of financial and human resources; and lack of ability to manage cooperative operations as the weaknesses of cooperatives [19]. To overcome these weaknesses and develop the cooperatives in Rwanda, capacity building of their members, financial support, and infrastructure expansion are required. However, establishing the foundation of self-reliance may be difficult for the primary cooperatives composed of smallholder farmers in rural areas using only internal human and financial resources due to the characteristics of smallholders and limited resources in the community. Therefore, the government and donors should ensure an environment favorable to cooperatives politically and institutionally and provide technical, managerial, and financial support to cooperatives to stand on their own feet.

South Korea is an example of the success of rural development with the government's active support for agricultural cooperatives. There has been criticism that it was a government-led cooperative movement, and the agricultural cooperatives were used as a means of conveying the government's rural policies and support. This is obviously against the principle of cooperatives. However, notably, the South Korean government directly provided large-scale support such as agricultural fund loans, extension service, and agricultural machinery support for the quantitative and qualitative growth of the National Agricultural Cooperatives Federation (NACF) in the 1970s and 1980s, and this intensive support was organically linked to community-level cooperatives through NACF. Consequently, this system and support contributed to increasing the income and strengthening the capacity of cooperative members and the community [20]. Although the basic values and principles of cooperatives focus on self-reliance by member-centered internal capital raising, management, and investment, the reality is that cooperatives in rural areas of developing countries are facing many challenges. Therefore, appropriate external support for members' capacity building, hard and soft infrastructure building, decision making, and management can promote the formation of a self-reliance base for cooperatives. 
Table 2. Weaknesses and opportunities of the cooperatives in Rwanda.

\begin{tabular}{|c|c|}
\hline \multicolumn{2}{|c|}{ Internal Environment of Cooperatives } \\
\hline Internal Weaknesses & External Opportunities \\
\hline $\begin{array}{l}\text { Weakness in causal aspect } \\
\text { - Weak internal communication system } \\
\text { - Lack of infrastructure (soft, hard) } \\
\text { - Limited financial and human resources } \\
\text { - Aging members and limited innovation } \\
\text { - Limited skills in cooperative management } \\
\text { and governance }\end{array}$ & $\begin{array}{l}\text { • Existence of political will } \\
\text { - Aligned with the national development framework } \\
\text { - Strong institutional and policy frameworks } \\
\text { - Existence of available support from development }\end{array}$ \\
\hline $\begin{array}{c}\text { Weakness in consequential aspect } \\
\text { • Limited ownership of members } \\
\text { - Weak self-help and diligence capacities of members, } \\
\text { which underpin the lack of sustainability of } \\
\text { cooperatives } \\
\text { • Failure to make decisions } \\
\text { - Limited social, economic, and institutional benefits } \\
\text { to cooperative members }\end{array}$ & $\begin{array}{l}\text { - Regional integration } \\
\text { - Accountable governance development niches for } \\
\text { cooperatives } \\
\text { - Strong emphasis on performance and delivery }\end{array}$ \\
\hline
\end{tabular}

\section{Results}

\subsection{General Information of the SMU Program in South Korea and Rwanda}

\subsubsection{SMU in South Korea}

SMU, which was a national rural community development policy led by the Park Chung-hee government in South Korea in the 1970s, was the main driving force behind modernization and development of rural areas. SMU, which emphasized the dedication of the leader and voluntary participation of the residents based on the SMU spirit of diligence, self-help, and cooperation, aimed to build the capacity of villagers, improve the living environment of the villages, and increase income and ultimately sought the economic self-reliance of the community. The government introduced various measures to increase agricultural productivity and farming and non-farming income. In particular, the government encouraged the promotion of income increase projects through cooperation between farmers and villages, and through this, the organization and economic activities of cooperatives were activated. Consequently, South Korea achieved self-supply of rice in 1976, and rural household income recorded a six-fold increase from 255,800 KRW in 1970 to 1,531,300 KRW in 1979 [21]. Moreover, the quality of life of the rural residents improved by producing tangible output such as improvement of village roads and housing and supply of electricity. After South Korea became a donor country, the government and the organization related to SMU have been sharing their development experience with developing countries by implementing SMU-based rural community development projects and providing SMU training.

\subsubsection{Rwanda SMU ODA Program and Its Implementation}

The SMU ODA program in Rwanda was launched in 2010 by the provincial government of Gyeongsangbuk-do with the Korea International Cooperation Agency (KOICA) and implemented in four pilot villages in rural areas as a five-year program. The annual budget for each village was about 100 thousand USD, and the South Korean project managers (PMs) were dispatched to conduct the project with local residents and manage the project cost. Figure 1 shows the overall implementation structure of the SMU project and the relationship between stakeholders. The village project was funded $100 \%$ by the South Korean government, and the Rwandan government cooperated with the PMs to ensure that the project was conducted smoothly and encouraged the villagers to participate. The main counterpart that was directly involved in the project was the sector-level officials, and the Saemaul Undong 
Committee (SMUC) was organized at the village level considering the existing leaders and associations there. The SMUC consisted of SMU leaders, members of the Village Steering Committee, and leaders of sub-projects and played a critical role in implementing projects and promoting the participation of the residents.

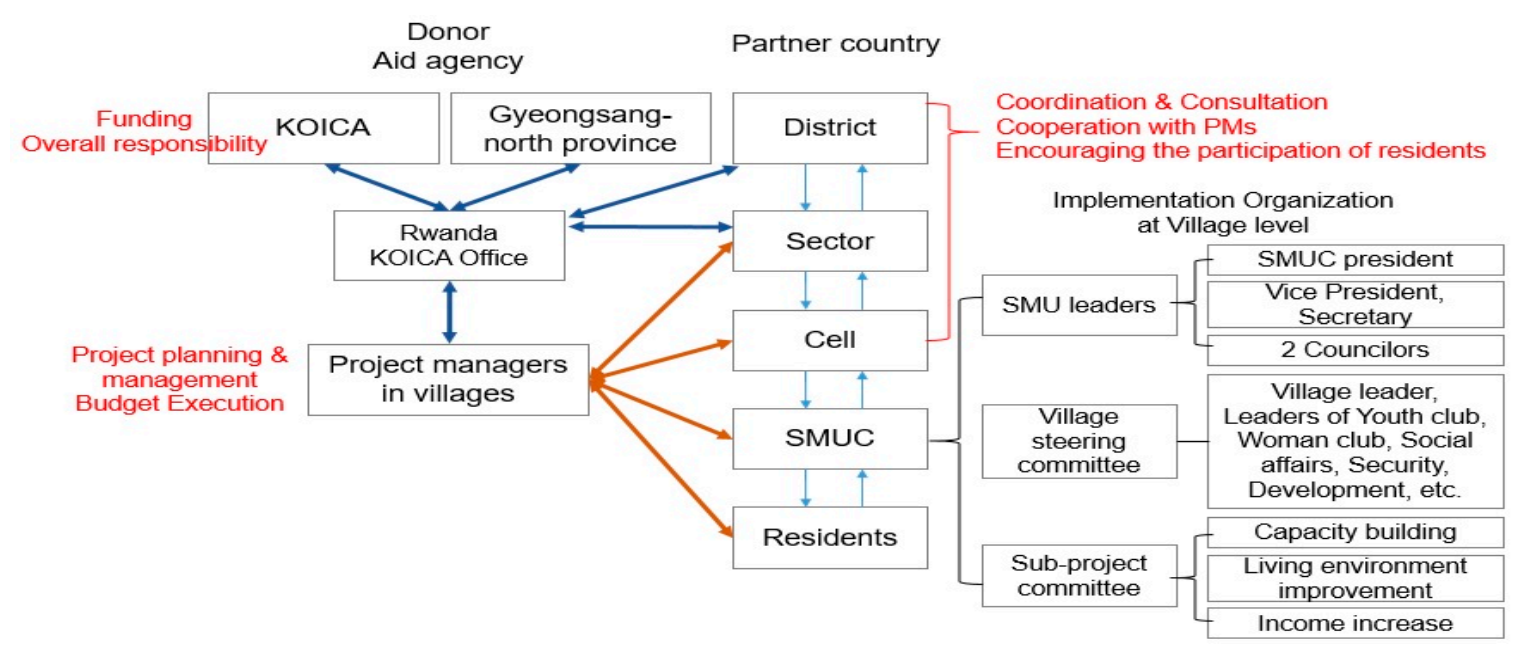

Figure 1. SMU project implementation structure. Source: own.

The village project was decided by the South Korean PMs and SMUC members through discussion. The PMs made an action plan reflecting the residents' opinions and the total budget allocated to several village projects according to their scale. PMs played the role of a facilitator, consultant, and coordinator in the project's implementation. As the SMUC, which consists of residents, had limitations in planning and implementing projects and achieving the stated goal on its own within the project period due to lack of capacity, the PMs led the project to be conducted according to the action plan, promoting the SMUC to actively participate and take initiative gradually. Through weekly regular meetings with the SMUC, the PMs collected the villagers' opinions, adjusted and drew up the weekly and monthly project implementation plans, and executed the project cost.

The SMUC took an important role as a main project implementation body in the village, but its influence was only valid within the village project, as it was not government authorized. Consequently, it became difficult for the SMUC and leaders to continue the projects or expand their scale beyond the village unit once the donor's official support was withdrawn. Particularly, in the case of a communal project for income generation such as communal breeding of livestock or village communal farm, the project itself is likely to break apart once the aid ends unless property or operational rights are clearly transferred to certain organizations or the project itself is profitable enough to sustain. In these circumstances, cooperatives can be a good alternative. Unlike project committees or associations, cooperatives can achieve legal personality from the government and seek profit by doing business and expanding the business area locally beyond the village unit within legal and regulatory frameworks as autonomous and independent organizations.

\subsubsection{SMU ODA Program in Gihogwe Village}

Among the four pilot villages, Gihogwe is a small village of approximately 270 households and 1270 people, located in Musambira Sector, Kamonyi District, in Southern Province. Although Gihogwe is part of the Southern province according to the administrative division (Figure 2), the village islocated in the center of Rwanda and takes about $90 \mathrm{~min}$ by car from the capital city, Kigali. However, due to the poorly developed roads and public transportation in Rwanda, it is difficult to move to other areas. Especially, the estimated $3.3 \mathrm{~km}$-long access road to the village from the paved main road (NR1) is sloped and unpaved, resulting in poor accessibility to the village. 


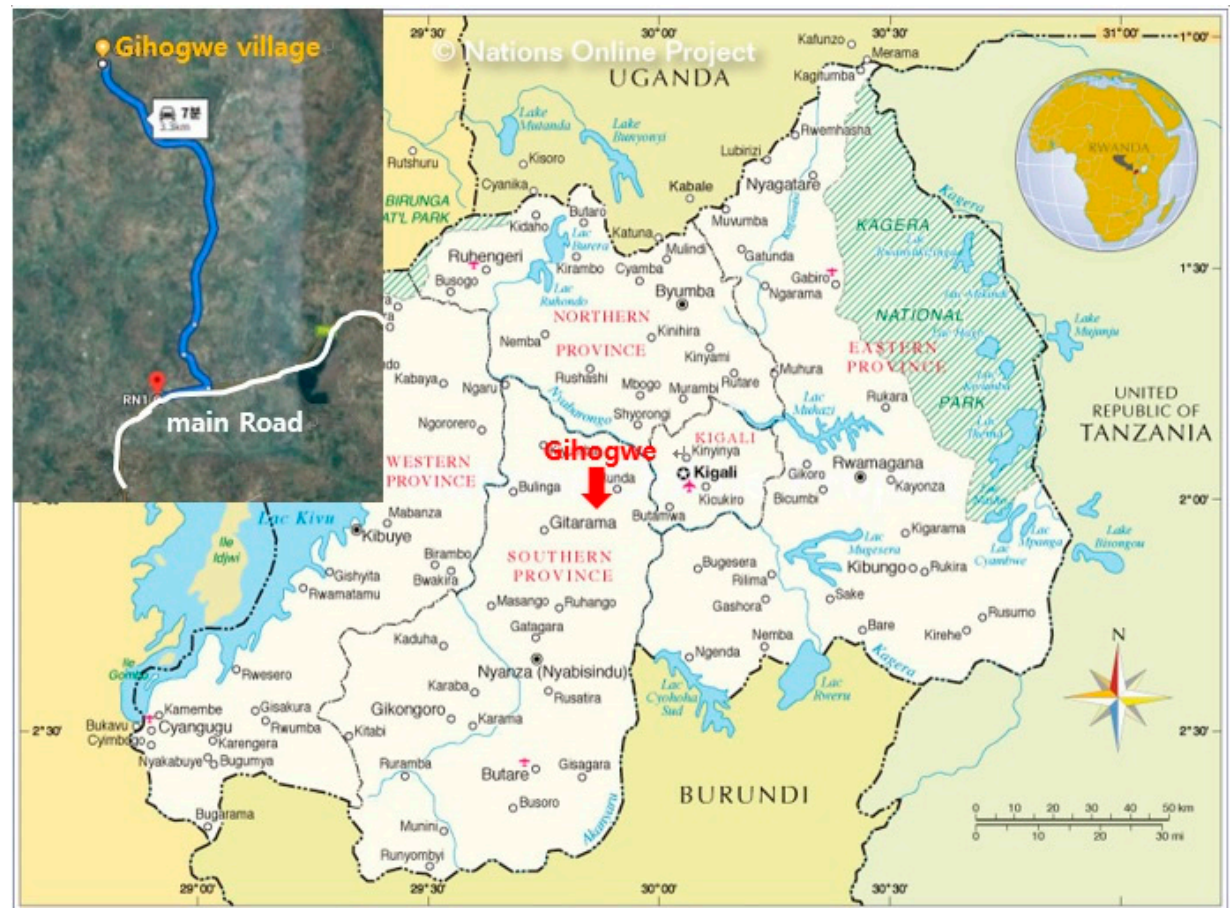

Figure 2. Location of Gihogwe village in Rwanda. Source: Nations Online Project map, Google maps (online).

According to the results of the 2013 baseline survey conducted by KOICA, the median income level of the village was 80,000 RWF. The main source of income for households was agriculture, but products were consumed mostly by households due to the small size of farming and low productivity. Various projects were conducted for five years to enhance the residents' capacity, improve their living environment, and increase income. Table 3 shows the village development projects that were implemented from 2011 to 2016 by year.

Table 3. SMU ODA projects in Gihogwe village in 2011 2016.

\begin{tabular}{|c|c|c|c|c|c|}
\hline Category & 1st Year & 2nd Year & 3rd Year & 4th Year & 5th Year \\
\hline $\begin{array}{l}\text { Capacity } \\
\text { building }\end{array}$ & & $\begin{array}{r}- \text { Adu } \\
- \\
-W\end{array}$ & $\begin{array}{l}\text { changin } \\
\text { class } \\
\text { b lub }\end{array}$ & \multicolumn{2}{|c|}{$\begin{array}{c}\text { - Social development } \\
\text { lessons }\end{array}$} \\
\hline $\begin{array}{c}\text { Living } \\
\text { environment }\end{array}$ & $\begin{array}{l}\text { - Village hall } \\
\text { construction }\end{array}$ & $\begin{array}{r}-\mathrm{M} \\
-\mathrm{Hor}\end{array}$ & $\begin{array}{l}\text { ove } \\
\text { ring }\end{array}$ & & \\
\hline $\begin{array}{l}\text { Income } \\
\text { increase }\end{array}$ & & & $\begin{array}{l}\text { farming } \\
\text { ice coope }\end{array}$ & $\begin{array}{l}\text { - Lives } \\
\text { - Lives }\end{array}$ & $\begin{array}{l}\mathrm{k} \text { association } \\
\text { a project } \\
\text { a cooperative }\end{array}$ \\
\hline
\end{tabular}

Source: own.

Since the Rwanda SMU ODA program was a pilot program, PMs were able to select, design and launch a new project every fiscal year through consultation with the village representatives, and the project was continued or stopped depending on the performance and sustainability. The scale of support was also different for each project. In the case of the rice farming project that started in the first year, a large budget was allocated every year as a representative income increase project, but relatively small budgets were allocated for new projects. 
In the first year of the program, the focus was on education, targeting the residents to enhance their understanding of the SMU ODA program, and village hall construction. Rice farming-an income generation project-was started under the initiative of the South Korean PMs. In addition to the rice farming project, other income projects-livestock bank and banana project-were also launched and implemented in the third and fourth year of the program to increase the income of residents who could not participate in the rice farming project and to diversify their income sources. These projects produced positive results. Especially, the two cooperatives and one association, which were created as part of the income increase project implementation, reflected the notable performance of the SMU ODA program. Generally, support to cooperative movements through foreign aid is provided in two ways. The first is to support the existing cooperatives, aiming at the development of the cooperative movement, and the other is to establish cooperatives as a tool for delivering aid and providing services to the poor by directly supporting the cooperative. In the case of the Rwanda SMU ODA program, the aid agencies set up the strategy to establish cooperatives and use them for income generation for ensuring self-reliance in line with the Rwanda cooperative movement policy. After the end of the five-year program, the aid agencies continued the "ex-post management program", targeting cooperatives such as the provision of training and facility maintenance.

\subsection{Banana Producers' Cooperative in Gihogwe Village}

\subsubsection{Banana Plantation Project and Cooperative}

Banana is a staple food of the Rwandan people, and its annual consumption per person is $227 \mathrm{~kg}$. Banana production in Rwanda averages at approximately 2.5 million metric tons per year, grown on about 165,000 ha, and occupies $23 \%$ of all arable land in the country [22]. Likewise, more than half of the Gihogwe village residents grew banana on a small scale, and the total area of banana plantation was approximately 60 ha (2014 Musambira sector office Internal Statistics). However, income from banana farming was considerably low, because most residents were growing the local breed that was vulnerable to diseases and low in productivity. They did not properly manage the banana cultivation due to lack of knowledge and skills. According to a 2014 internal survey of the banana project participants, the annual income from banana production was only about 63,000 RWF (equivalent to USD 92.4; 2014 Average Exchange Rate ( $\$ 1=$ Rwf681.86), Data resource: Korean Statistical Information Service, http://kosis.kr/statHtml/statHtml.do?orgId=101\&tblId=DT_2KAA811), and output per bunch was only about $12 \mathrm{~kg}$ (result of an internal survey of the banana project participants in 2014). While the average production of the improved banana bunch was 70 to $80 \mathrm{~kg}$ (figures based on the tissue-culture plant production company FAIM. 1td.'s own production results), the productivity of the banana in Gihogwe village was only one-fifth thereof. For these reasons, the "improved banana plantation project (banana project)" began in 2014 with the high demand of the residents and was conducted in earnest in 2015.

The banana project targeted villagers who grew banana, aiming at increasing banana productivity and improving agricultural skills and knowledge. A total of 149 households were given 50 improvedtissue-culture banana plants, fertilizers, and monthly training on banana cultivation. Consequently, a total area of 6.7 hectares (10\% of the existing banana plantations) was converted into a plantation of an improved banana breed, and the project members received nine instances of monthly agricultural training.

Discussions on the establishment of the banana cooperative began at the banana project committee's weekly meeting after the completion of seedling transplantation. There was some rationale behind the request to establish a cooperative. First, an increase in banana production was expected, because most project participants successfully planted the banana seedlings and the growth of plants were good. Project committee members argued the need for a cooperative for marketing and joint sales, and this also coincided with the strategy of the SMU ODA program on the income increase project for securing sustainability and self-help on the part of the cooperatives. Decisively, there was a demand from 
the project members (102 out of the 149 project members attended the project general meeting that took place to decide whether to establish the cooperative or not; 99 were in favor of the establishment). Steps were taken to obtain legal personality for the banana cooperative from April 2015 when the decision to establish a cooperative was made.

The goals of the banana cooperative were as follows:

- Marketing for increased banana production

- Reducing costs through joint purchase

- Securing project sustainability

- Diversification of businesses other than banana production.

In total, 124 out of the 149 project members joined the Gihogwe Banana Producers' Cooperative, named "KOPABUGI".

The legal registration process began in May 2015, and it took approximately four months to obtain formal approval from the Rwanda Cooperative Agency (RCA). During the registration process, six instances of training were provided for members, aiming at enhancing the understanding of the cooperative. The cooperative members had high expectations of increased yield and the benefits and services that the cooperative would provide and were extremely enthusiastic.

\subsubsection{Registration Process}

RCA is an institution that carries out the government policies concerned with cooperatives. It is in charge of the registration of cooperatives, assigning legal personality to cooperatives, supervision and regulation of the cooperative activities, education to strengthen the competence of cooperatives, and so on [23]. To acquire legal personality for cooperatives, the organization must get approval from the cooperative department in the sector and district level government in order by submission of the required documents; eventually, RCA issues the registration certificate after inspection of the documents and field. During the approval process, the officials in charge may request future business action plans of the cooperative or conduct an interview with the cooperative president in addition to the required documents to verify the organization's sustainable capabilities.

The banana project committee served as an interim election committee for the election of the cooperative board members. The board of directors, secretary, and treasurer were elected through a direct election, and an audit committee was formed by banana project members who applied to join the cooperative. Consequently, a committee of nine members (in Figure 3) was formed, and they played a leading role in the establishment of cooperative bylaws and the legal registration process.

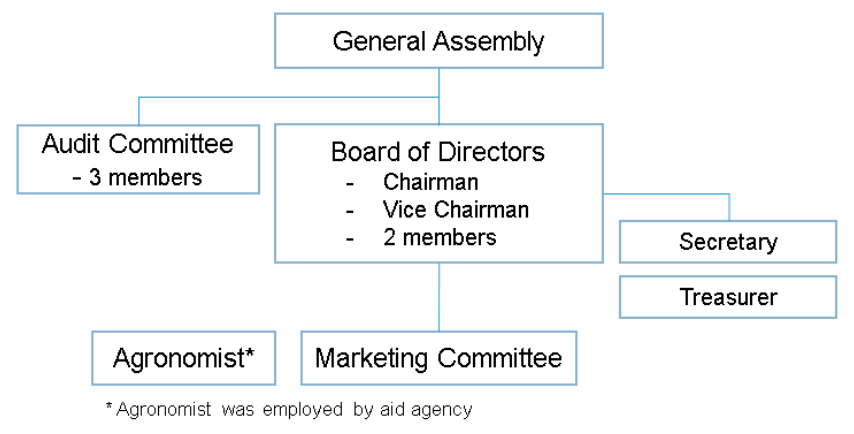

Figure 3. Organizational structure of KOPABUGI. Source: own.

The cooperative membership fee was set at $5000 \mathrm{Rwf}$ (approximately 7 USD; 2015 average exchange rate of Rwanda currency to the USD ( $\$ 1=$ Rwf719.86), data resource: Korean Statistical Information Service, https://kosis.kr/statHtml/statHtml.do?orgId=101\&tblId=DT_2KAA811) at a general meeting, and initially membership was limited to banana project members, but after formal registration was 
completed, any banana farmers in the community could join if they paid a membership fee and made a pledge to comply with the cooperative bylaws.

The bylaws contained articles on the overall operation of the cooperative, including banana harvests, collection and joint sales, cooperative fund raising, village fund raising, and fines, and all articles were enacted under the agreement of the members in the general meeting. The procedures for registration of the cooperative were carried out actively by the committee around the chairman of the cooperative; the PMs arranged and provided education for the cooperative members, supported the preparation of registration documents, and encouraged the committee to proceed quickly. Consequently, the banana cooperative was officially registered with the RCA in four months under the name of "KOPABUGI."

\subsubsection{The decline of KOPABUGI}

Since KOPABUGI was registered as a cooperative at the end of August 2015, it needed much preparation to play the role of a cooperative. First, continuous education on the role of cooperatives and management skills was necessary for the members. Further, as the first banana harvest was scheduled from June of the following year, preparation for banana sales such as the method of collection and storage, finding a market, and transportation was required. KOPABUGI was a new cooperative consisting of mostly poor smallholder farmers and needed support from the aid agency to strengthen their capacity and lay the foundation for self-reliance, as in the case of the growth process of the rice cooperative.

However, entering the fifth year of the program (the last year of the program) in October 2015, changes occurred in the degree of support and involvement of the PMs in projects. The aid agency and managers concentrated on the main project-the rice farming project-and reduced support and intervention for other projects as part of the exit strategy. New PMs asked KOPABUGI for their demands to make the last year's plan and budget, and KOPABUGI requested support for setting up the cooperative office. In response, the aid agency suggested that it would provide office construction costs on the condition that the cooperative provided a site for the office. The committee of KOPABUGI decided to purchase the land at the General Assembly meeting in April 2016, but at that time, KOPABUGI not only had no assets, but also had no sales income, because it was before the banana harvest. KOPABUGI received a loan from the Savings and Credit Cooperative (SACCO) at an annual interest rate of $21 \%$ and bought land in Gihogwe village for 1.8 million RWF. The office construction began in June 2016, and KOPABUGI barely managed to make a banana supply contract with banana processing companies and raised its sales income since the first harvest began in May 2016. However, KOPABUGI eventually failed to repay the loan within the repayment period, and consequently was on the verge of losing the building if the loan including interest was not redeemed promptly. The only way to repay the loan was to raise money by selling the building. Residents insisted on solving the issue within the village, because the cooperative office building was built with the support of the SMU ODA project. Finally, the rice cooperative, which was established and supported by the SMU project, decided to buy the building with its fund. Although KOPABUGI repaid the loan, the ownership of the building was transferred to the rice cooperative.

This incident caused the collapse of KOPAGUGI, which lost its value. The decisive factors of KOPAGUGI's decline were loan repayment failure and loss of confidence among the cooperative members; however, KOPAGUGI had already faced a variety of challenges and experienced failure before the incident. These events occurred in the last year of the program, and the consequences of the failure to repay the loan occurred after the program was terminated.

This section seeks to learn more about the series of events (Figure 4) that have taken place since the establishment of the cooperative and analyze the causes of KOPABUGI's failure. 


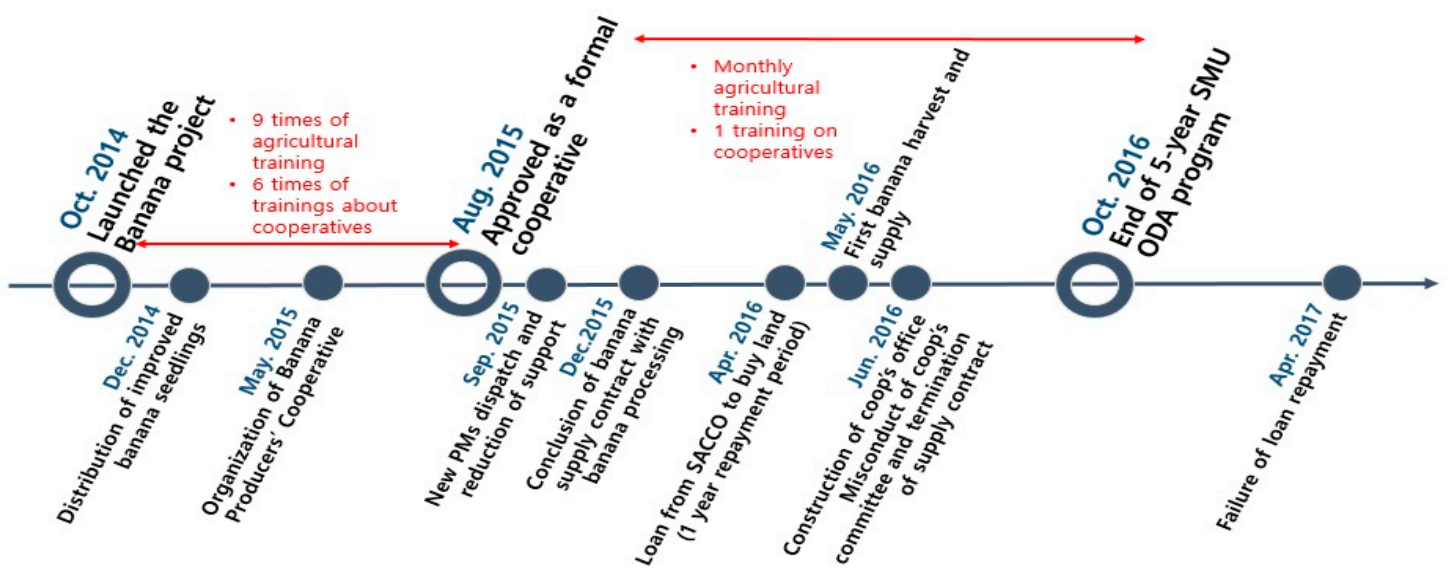

Figure 4. Timeline of major events of the banana project and KOPABUGI. Source: Own.

As aforementioned, KOPABUGI needed support from the aid agency to strengthen the members' capabilities and build a foundation for the cooperative's self-reliance since its establishment. However, the aid agency and PMs reduced the support and intervention for KOPABUGI.

The first difficulty that KOPABUGI faced was in the search for the market, conclusion of the supply contract, and the creation of revenue from the sale of increased banana output; the second was that it bought the land for the cooperative's office by taking out loans due to wrong decision-making. The third was the misconduct of the cooperative's committee, which resulted in the disruption of the sales contract, followed by the sale of the office due to the failure of loan repayment, resulting in the loss of assets and funds of its members.

\section{Marketing Failure and Falling Market Prices}

One of the main objectives of KOPABUGI was to reduce the personal transaction cost and transport cost through the joint sales of increased production. As the Musambira sector, where the village is located, did not have a large market, it was necessary to search for a market for bananas. In addition, as the three banana varieties distributed to the residents as per their demands had different consumption purposes, it was required to find different markets. However, the board of the cooperative, which lacked experience, capacity, market information, and networks, faced difficulty in marketing. To make matters worse, increased banana production across the country in 2016 caused banana prices to fall. KOPABUGI managed to make a semimonthly supply contract on the condition of receiving 80 RWF per $1 \mathrm{~kg}$ with the banana beer factory in the Gisagara district. The price was 20\% lower than the average market price of bananas in 2015. Moreover, as the factory was located about $120 \mathrm{~km}$ away from Gihogwe village, transportation had a high cost, but sales volume was too small compared to the total banana production (in Table 4). Moreover, the only banana variety that was supplied to the factory was FHIA 25, used for making juice; resultantly, members who mainly produced bananas for cooking and dessert purposes had to find their own market. The cooperative's failure to play the roles that its members expected and lack of benefits offered made members feel skeptical about the cooperative's necessity.

Table 4. Estimated banana sales income and transportation costs.

\begin{tabular}{ccccc}
\hline Supply & $\begin{array}{c}\text { Quantity } \\
(\mathbf{k g})\end{array}$ & $\begin{array}{c}\text { Sales Income * } \\
\text { (RWF) }\end{array}$ & $\begin{array}{c}\text { Transportation } \\
\text { Cost (RWF) }\end{array}$ & $\begin{array}{c}\text { Ratio of Transport } \\
\text { to Sales (\%) }\end{array}$ \\
\hline 1st & 4500 & 360,000 & 50,000 & 13.9 \\
2nd & 5500 & 440,000 & 70,000 & 15.9 \\
3rd & 9500 & 760,000 & 120,000 & 15.8 \\
Total & 19,500 & $1,560,000$ & 240,000 & 15.4 \\
\hline
\end{tabular}

* Sales quantity $(\mathrm{kg}) \times 80$ RWF. Source: Interview with the agronomist who worked as a local employee of the banana project. 
Wrong Decision-Making and Failure of Loan Repayment

KOPABUGI, which had to arrange a site to receive support for the construction of the cooperative office from the aid agency, decided to buy the land by taking out a loan in the General meeting and took out a loan from SACCO. KOPABUGI decided to buy the land in April 2016, before the banana harvest began in earnest. As there were no assets or cooperative capital, it was clearly a wrong decision to purchase the office site with a loan. KOPABUGI also used some space in the village hall, which was built under the SMU ODA Project, as an office; therefore, it was not necessary to build an office, even after taking out the loan.

In addition, in the process of repaying the loan, it appeared that the KOPABUGI board did not take active action. It would have been difficult to seek help, because at the expiration of the repayment period, there was no project support by the aid agency. KOPABUGI board members should have gotten members to understand the situation and saved money to pay off the loan, but they did not. It seems that, because of the board members' lack of experience in banking, they did not fully understand and, therefore, neglected the consequences. Consequently, ownership of the building was transferred to the rice cooperative, and they could clear off the debt. Members' distrust of the cooperative intensified after that, and the banana cooperative stopped functioning.

The balance of assets, debt, and capital are the indicators measuring the operational stability of cooperatives, and these factors must be considered in making business decisions [24]. However, the KOPABUGI board members took an excessive loan to purchase land for the cooperative office without any consideration of the financial situation, and it directly showed that they were lacking the capacity to manage the cooperative.

\section{Lack of Leadership and Misconduct of Board Members}

The hard-won banana supply contract with the banana beer factory ended only with a four-time supply due to the leader's misconduct. In the fourth supply, the KOPABUGI president secretly shipped bananas to the factory with the knowledge of only several members, supplied them under the name of the cooperative, and took the sales revenue. However, this misconduct was revealed soon; the factory terminated the contract immediately, and the cooperative members complained strongly. This was due to a lack of leadership, responsibility, and ethics of the board members and also resulted from a lack of cooperative members' participation in the cooperative business.

The sense of responsibility of the board members could be strengthened through continued education. In addition to the lack of competence and responsibility of the board members, lack of monitoring from members and the aid agency made them more likely to commit irregularities.

\subsubsection{Causal Analysis of KOPABUGI's Failure}

Figure 5 shows the causes of KOPABUGI's failure. The broken trust between the members and the board of directors resulted in the failure. Many causes were attributed to the results of the decline and failure of KOPABUGI, but the underlying causes can be summarized as constraints due to the lack of capacity of the cooperatives' members and board members, a lack of understanding of cooperatives, and the absence of assets and funds.

\section{Lack of Capacity of the Board Members}

Since the purpose of establishment of KOPABUGI was to expand the banana production scale, maintain price bargaining power through joint sales, and expand cooperative business, these contents were included in the bylaws. According to the bylaws, members had to double the cultivation area of improved banana breed through transplantation of banana suckers, provide $90 \%$ of the banana production to the cooperative for joint sale, and $20 \%$ of the proceeds should be saved for cooperative funds. 


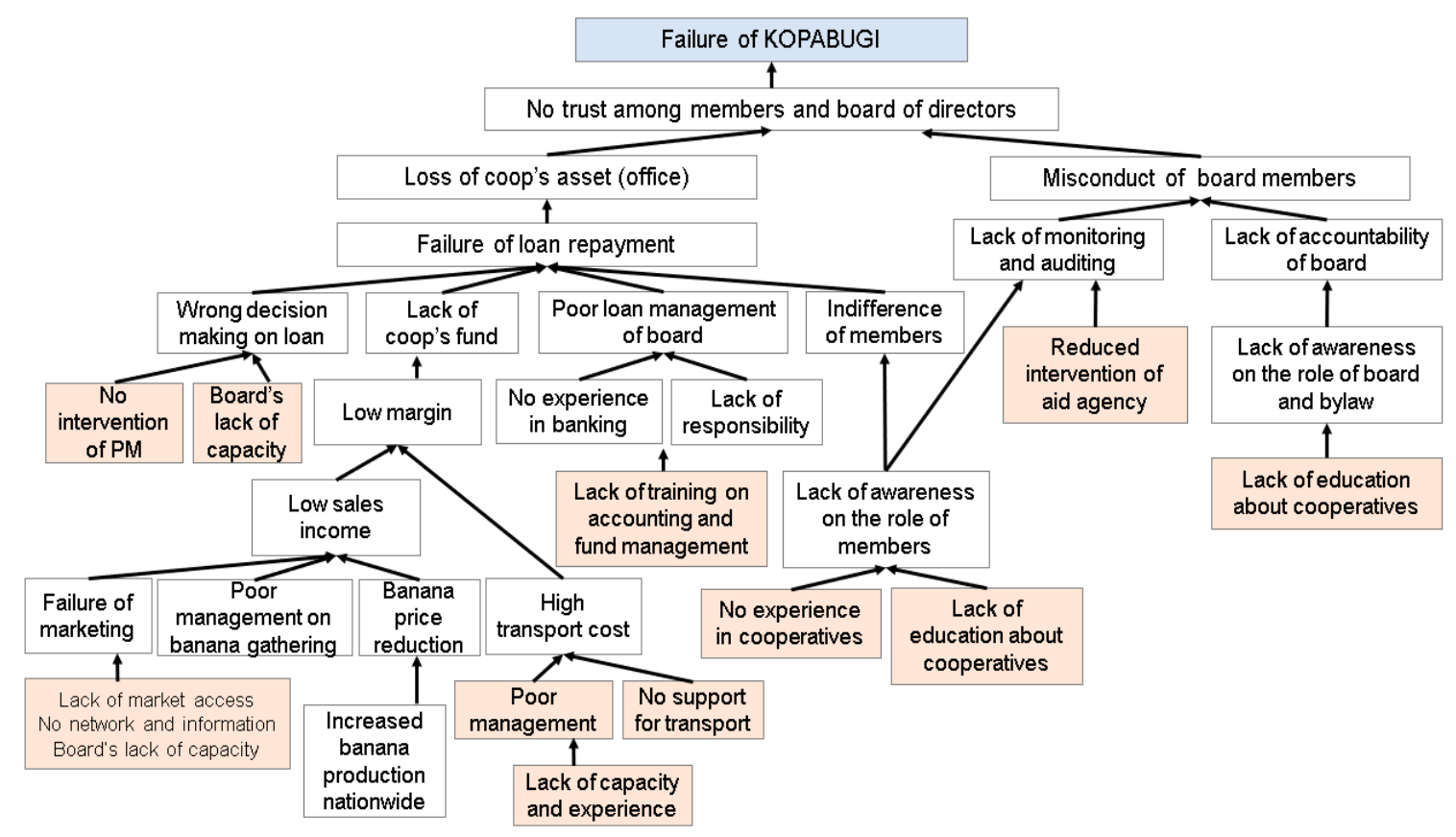

Figure 5. Causal analysis of KOPABUGI's failure. Source: own.

The goal to expand the banana cultivation area was achieved by the individual activities of members. However, the goal of accumulating cooperative funds was not achieved at all due to the failure of marketing and poor banana-collecting management. The committee had only expectations for increased banana production and increased income from joint sales but did not make specific plans on how to manage banana gathering and storing, transportation costs, and distribution of sales revenue. The banana variety that signed a supply contract with the banana beer factory was PHIA 25 for juice, and it was estimated that the amount produced by the cooperative members was about 200 tons. There was no exact data on the total yield, but the average weight per banana bunch was $50 \mathrm{~kg}$, measured by agronomist after harvest, and about 4000 PHIA 25 bananas were grown, so it was estimated that the production of PHIA 25 bananas in 2016 was $200,000 \mathrm{~kg}$. However, the amount of bananas supplied to the factory was only $19,500 \mathrm{~kg}$, less than $10 \%$ of the total production. For this reason, in fact, the validity of collecting bananas for joint sale and cooperative funds was lost.

Good governance and effective and efficient management of cooperatives highly depend on the competence of the board of directors. However, KOPABUGI was a fledgling cooperative that acquired legal personality in August 2015, and the board members had no experience in the management of cooperatives. Moreover, they had a low level of education like the cooperative members; therefore, intensive education about cooperative operation and financial management was necessary.

Although the one-year period since the establishment of KOPABUGI was extremely crucial to lay the foundation of the cooperative, the aid agency reduced its support for KOPABUGI and provided education about cooperatives only once in the last year of the ODA program. While "education, training, and information", the fifth principle of cooperatives, is a task that cooperatives fulfill independently, KOPABUGI had neither any human resources with expertise nor the funds to invite outside instructors at that time. For this reason, although educational support to enhance the competence of the board members and consultation in making decisions through appropriate monitoring were required precisely, support or intervention by the aid agency and PMs was insufficient. The content and scale of aid was finally decided by the PMs and aid agency; thus, it is difficult to ascertain why training for KOPABUGI was not sufficiently supported in the last year of the program. However, it was clear that since the decision to establish a cooperative a total of six training sessions was provided for KOPABUGI members, and four intensive training sessions were provided to the committee in the fourth year of program, whereas only one training has been provided in the fifth year. 
Lack of Capacity of the KOPABUGI Members

The rice farming project, livestock bank project, and banana project were the representative income increase projects that were implemented in Gihogwe village. While the rice farming project was launched in the first year of the program and livestock bank project in the third year, the banana project was launched in the fourth year. Out of the 149 households participating in the banana project, 84 had experience of participation in other income increase projects, but 65 households, that is, $44 \%$ of the Banana project members (Table 5), had no experience of joining an SMU income project. Moreover, 84 out of the 124 KOPABUGI members, that is, $66 \%$, were joining a cooperative for the first time. Only the remaining 40 had the experience of participating as members of the rice cooperative in Gihogwe. Despite the fact that continuous and intensive training on the cooperative and the role of its members was essential for the foundation building of KOPABUGI, there were no efforts toward it from either the aid agency or KOPABUGI itself.

Table 5. Number of the banana project participants who are duplicated in other income increase projects.

\begin{tabular}{cccccc}
\hline & $\begin{array}{c}\text { Rice Co-op \& } \\
\text { Livestock Bank \& } \\
\text { Banana Project }\end{array}$ & $\begin{array}{c}\text { Rice Co-op \& } \\
\text { Banana Project }\end{array}$ & $\begin{array}{c}\text { Livestock Bank \& } \\
\text { Banana Project }\end{array}$ & Banana Project Only & Total \\
\hline $\begin{array}{c}\text { Banana Project } \\
\text { members }\end{array}$ & 24 & 20 & 40 & $105^{* *}$ & 149 \\
$\begin{array}{c}\text { Sub-total } \\
\text { Banana } \\
\text { Co-op member }\end{array}$ & $44^{*}$ & $40^{* * *}$ & $84^{* * * *}$ & 124 \\
\hline
\end{tabular}

${ }^{*}$ Number of banana project members who are members of the rice cooperative. ${ }^{* *}$ Number of Banana Project members with no experience in joining a cooperative. ${ }^{* * *} 40$ out of 44 join a Banana cooperative. ${ }^{* * *} 84$ out of 105 join a Banana cooperative. Source: own.

A cooperative can be analyzed as a coalition driven by various participants such as farmers, board members, employees, input suppliers, and buyers, and the cooperatives' economic performance and welfare of farmers could be improved by the structure and practice of cooperatives [25]. Each participant has a role and relationship as a stakeholder. Cooperative members, as both owners and users, are also responsible for the operation and success of the cooperative.

However, KOPABUGI did not have a mechanism for members to participate in decision making or business actively, and members just followed the decisions of the board members who communicated directly with the PMs, and they were negligent in the board's monitoring activities. Many members of the Banana project agreed to the establishment of the cooperative. However, it also may have been due to their unconditional trust in the South Korean PMs and the banana project without a basic understanding of the cooperative.

Looking at the decline of the banana cooperative, it is clearly seen that KOPABUGI also had most of those weaknesses stated in the SWOT analysis of Rwandan cooperatives. Lack of capacity and ownership of members; limited skill in cooperative management and governance; limited financial and human resources; failure in decision making; lack of infrastructure; and limited social, economic, and institutional benefits to members of the cooperative were the causes of KOPABUGI's failure. In the last year of the SMU ODA program, KOPABUGI was in desperate need of assistance from the aid agency for capacity building, soft infrastructure building, operational management, and marketing, and although aid agency was able to provide such assistance sufficiently, the assistance that they really needed was not provided.

Today, KOPABUGI has lost its qualification as a cooperative, and most of its members are not involved in any cooperative activities. Only about 50 members have tried to get together and have been collecting a small amount weekly for microfinance. However, this has nothing to do with the purpose of KOPABUGI, and it may be fair to say that it has completely lost its value as a banana producers' cooperative. 


\subsection{Gihogwe Rice Producers' Cooperative, CODARIKA}

The rice farming project initiated by the South Korean PMs was launched with 65 residents who had land in marshlands near Gihogwe village in 2011, the first year of the SMU ODA program. In 2004, the Rwandna government transferred the ownership of the marshlands from individual to state; therefore, in effect, the farmland ownership belongs to the government, but the residents, who had originally owned the farmland, are accorded land-use rights. They converted the marshland to rice paddies and were equally allotted two paddy plots under the coordination of the local government. For the rice farmers in Rwanda, it was inevitable to organize a rice producers' cooperative and directly sell their products to licensed rice millers at the community level. This was because the Ministry of Trade and Industry introduced a single-channel fixed-price marketing scheme for rice, banning the business of rural traders and small-scale rice mills in 2012 [26]. For this reason, the Rice Producers' Cooperative, CODARIKA, was established with 65 members and acquired legal personality from the government in 2012. The main goal of CODARIKA was to reduce production cost through the joint purchase of agricultural materials and joint use of cooperative facilities, strengthen the price negotiation power through high productivity and quality, reduce transportation cost, and enhance capacity building of members.

CODARIKA continuously received considerable support for infrastructure construction and maintenance such as an irrigation system, dam construction, a cooperative office, storage, and a rice drying place during the five years of the program. For three years after the beginning of the SMU ODA program, all the costs of farming, infrastructure building, and training were totally funded by the aid agency, apart from the residents' labor force. From the fourth year, the aid agency asked CODARIKA members to pay part of the cost of purchasing seeds, fertilizers, and pesticides to promote self-reliance of the cooperative and reduce members' dependence on the aid agency. However, the costs for infrastructure construction and maintenance were still fully supported until the end of the SMU ODA program, and the costs of irrigation and dam extension and maintenance continued to be supported during the ex-post-project period only.

In addition, the PMs constantly intervened in the management of CODARIKA, monitored the operation status, and acted as advisors in the decision-making process. The rice project was highly regarded as a successful income increase project of the SMU ODA for producing rice that was not previously produced in this area by converting unused marshlands into farmland and generating income. The local government actively cooperated in the project. Therefore, support and attention of the aid agency was mainly focused on the rice farming project.

As shown in Table 6, CODARIKA, starting with 3 ha and 65 members in 2011, expanded its scale to villages located around the marshlands every year beyond the scope of Gihogwe village, and the total farming land reached about 80 ha in 2016, the last year of the SMU ODA program. By 2017, CODARIKA grew into a mid-sized cooperative with a total of 1054 members and 110 hectares of rice paddies [27].

Table 6. No. of CODARIKA members and size of rice paddies from 2011 to 2016.

\begin{tabular}{ccccccc}
\hline & $\mathbf{2 0 1 1}$ & $\mathbf{2 0 1 2}$ & $\mathbf{2 0 1 3}$ & $\mathbf{2 0 1 4}$ & $\mathbf{2 0 1 5}$ & $\mathbf{2 0 1 6}$ \\
\hline Paddy area & 3 ha & 12 ha & 15 ha & 30 ha & 45 ha & 80 ha \\
\hline $\begin{array}{c}\text { Cooperative } \\
\text { members }\end{array}$ & 65 & 65 & 88 & 164 & 289 & 370 \\
\hline \multicolumn{7}{c}{ Source: Internal data of rice farming project report. }
\end{tabular}

CODARIKA did not grow amicably without any problems. In the fourth year of the program, it was revealed that the president of the rice cooperative misappropriated the cooperative funds for personal interest, and there were many accounting problems. The cooperative members were upset by the facts that had been revealed, but at the same time confused as to how to resolve them. In such a situation, the PM who was in charge of the rice farming project intervened and took active actions. 
Several General Assembly meetings were held by the board of directors, where members discussed possible solutions to this problem. The General Assembly meeting continued until consensus was achieved, and finally, members changed the president and gave penalty to the members who conspired in the misappropriation. The newly elected chairman was young and dedicated to the cooperative. The PM intervened in the process in which the cooperative members reached an agreement and elected a new president and helped the new president learn how to manage a cooperative while ensuring its autonomy and independence.

The rice cooperative has built sufficient hard and soft infrastructure, and the capacity of not only the committee but also its members has been greatly strengthened through continuous education by aid for a period of five years. The benefits of the cooperative for members were not only cost reduction through joint purchase of agricultural materials such as fertilizers and seeds, but also securing stable productivity through joint seed germination and farmland management. It could attempt to diversify income sources by investing in the breeding of pigs and cattle with cooperative funds accumulated by collecting some of the rice sales revenue from members. In addition, it contributed to the improvement of the welfare of members by providing services such as micro-finance and health insurance payments.

\subsection{Comparison of KOPABUGI and CODARICA}

KOPABUGI and CODARICA were the output of the SMU ODA program, but their future turned out completely different. It is difficult to simply analyze ODA's influence on the success or failure of the cooperatives, because there are differences in their background, purpose, and main activities and in the production and domestic market environment of the two crops, rice and banana.

CODARIKA was established to reduce costs and obtain price bargaining power through the cooperative, because the rice-growing farmers were virtually unable to trade or process rice. Accordingly, CODARIKA had no pressure on marketing for rice sales. As all marshlands are government-owned, only residents with land-use rights could join the cooperative, and only two plots of farmland per household could be allocated.

As rice farming initiated by the SMU ODA project was the first to be attempted in the project area, it had no infrastructure at all. Therefore, the aid agency provided full support for cultivating marshlands, building irrigation systems and small dams, and constructing cooperative offices, drying places, and warehouses. As the organization and operation of the cooperative was also the first attempt, the South Korean PMs were deeply involved from the stage of the establishment to management of the cooperative and provided continuous education about cooperatives and rice farming during the program period.

On the other hand, KOPABUGI, which was created as a result of the "improved banana plantation project", was mainly aimed at exploring the sales market, acquiring price bargaining power through joint sales, and increasing income through value-added creation. Any resident who grows bananas could join by paying a membership fee and expand the size of their banana plantation, depending on the area of the field they owned.

Since improved banana seedlings were successfully transplanted in January and February 2015 and the climate was also suitable for banana growth, the first harvest, which began around June 2016, was expected to be extremely successful. Therefore, sales market research and finding buyers were of paramount importance, and thorough preparation of internal procedures for joint sales such as gathering, storing, and transportation of banana was required. However, KOPABUGI did not receive this support from the aid agency. This was attributed to a lack of vision and strategy in the planning and implementation of the ODA project.

Comparing the support that the two cooperatives received from the aid agency (Table 7), there were significant differences in the duration and scale of support and the PMs' degree of involvement, as well as in the process of solving problems within the cooperative and the subsequent actions. KOPABUGI failed to solve its internal problems regarding the president's misconduct and financial crisis. 
Table 7. Comparison of CODARIKA and KOPABUGI.

\begin{tabular}{|c|c|c|}
\hline & CODARIKA & KOPABUGI \\
\hline Establishment & With 65 members in 2011 & With 124 members in 2015 \\
\hline Project period & 5 years $(2011 \sim 2016)$ & 2 years (2014 2016) \\
\hline Status quo & $\begin{array}{l}1054 \text { members } \\
\text { Covering over } 10 \text { villages }\end{array}$ & $\begin{array}{l}\text { Around } 50 \text { members } \\
\text { in only Gihogwe village }\end{array}$ \\
\hline Main goal & $\begin{array}{l}\text { - Increase productivity } \\
\text { - Lower agricultural costs through } \\
\text { joint purchases }\end{array}$ & $\begin{array}{l}\text { - Marketing and joint sales } \\
\text { - Expansion of the cultivated area of } \\
\text { the improved banana variety } \\
\text { - Lower agricultural costs through } \\
\text { joint purchases }\end{array}$ \\
\hline Farming & $\begin{array}{l}\text { - Each member grows rice on } \\
\text { the allocated } 2 \text { plots of land in } \\
\text { large-scale farmland reclaimed from } \\
\text { marshlands }\end{array}$ & $\begin{array}{l}\text { - Each member grows bananas in their } \\
\text { own field in village }\end{array}$ \\
\hline $\begin{array}{l}\text { Challenges } \\
\text { in farming }\end{array}$ & $\begin{array}{l}\text { - Water supply and irrigation } \\
\text { - Weather (flood and drought) } \\
\text { - Disease- Management of seed } \\
\text { germination } \\
\text { - Increase productivity }\end{array}$ & $\begin{array}{l}\text { - Water supply } \\
\text { - Weather (drought) } \\
\text { - Disease }\end{array}$ \\
\hline Income & $\begin{array}{l}\text { - Rice sales } \\
\text { - Depending on the yield of rice from } 2 \\
\text { plots }\end{array}$ & $\begin{array}{l}\text { - Banana sales } \\
\text { - Value added can be created through } \\
\text { banana processing; for example, } \\
\text { banana wine, chips, juice, etc. } \\
\text { - Members can expand their } \\
\text { cultivation area according to the size } \\
\text { of land owned by individuals }\end{array}$ \\
\hline $\begin{array}{l}\text { Support } \\
\text { by agency }\end{array}$ & $\begin{array}{l}\text { - For } 5 \text { years (2011 2016) } \\
\text { - Construction of infrastructure } \\
\text { (2 dams, irrigation system, } 2 \text { storages, } \\
\text { drying place, cooperative office) } \\
\text { - Maintenance of infrastructure } \\
\text { - Cost for farming and sales } \\
\text { (seeds, fertilizers, pesticides, } \\
\text { transportation, sacks, etc.) } \\
\text { - Education and training for } 5 \text { years }\end{array}$ & $\begin{array}{l}\text { - For } 2 \text { years (2014 2016) } \\
\text { - Cost for farming only in } 2015 \\
\text { (banana plants, fertilizer) } \\
\text { - Cost for harvest (scale, sacks) } \\
\text { - Construction of cooperative office } \\
\text { - Education and training for } 2 \text { years }\end{array}$ \\
\hline $\begin{array}{l}\text { The degree of involvement of } \\
\text { the South Korean PMs }\end{array}$ & $\begin{array}{l}\text { - High in 2011 2015 } \\
\text { - Moderate in } 2016\end{array}$ & $\begin{array}{l}\text { - High in } 2015 \\
\text { - Low in } 2016\end{array}$ \\
\hline $\begin{array}{l}\text { Overcoming } \\
\text { a crisis }\end{array}$ & $\begin{array}{l}\text { The misappropriation of cooperative } \\
\text { funds by the president } \\
\rightarrow \text { Resolving the problem through } \\
\text { continuous general meetings with all } \\
\text { members and replacing the president } \\
\rightarrow \text { It became an opportunity to } \\
\text { strengthen the solidarity of } \\
\text { the cooperative members }\end{array}$ & $\begin{array}{l}\text { Failure to repay the loan taken to } \\
\text { purchase the office building site } \\
\rightarrow \text { Disposition of cooperative office to } \\
\text { repay the loan and replacement of the } \\
\text { president } \\
\rightarrow \text { Loss of trust among members } \\
\rightarrow \text { Cooperative virtually collapsed }\end{array}$ \\
\hline $\begin{array}{l}\text { Challenges in cooperative } \\
\text { operation }\end{array}$ & $\begin{array}{l}\text { - Maintenance of cooperative facilities } \\
\text { and infrastructure } \\
\text { - Reduction of costs } \\
\text { - Cooperative member management }\end{array}$ & $\begin{array}{l}\text { - Marketing for joint sales } \\
\text { - Product collection and storage } \\
\text { - Reduction of costs } \\
\text { - Diversification of business to create } \\
\text { value added }\end{array}$ \\
\hline
\end{tabular}

Source: own.

\section{Discussion: Cooperatives and Social Open Innovation}

The failure of the banana cooperative was caused by a combination of factors, such as the lack of board members and members' capacity; the failure of rational decision-making; the failure of marketing; the lack of infrastructure, assets, and funds; and lack of adequate support and monitoring from the aid agency. 
Board members were not faithful to their roles, and members did not participate in the cooperative's economic and organizational activities. Social engagement is influenced by goal setting, such as sharing common goals, participation, and leadership, and can be strengthened by relationships, cooperation, and solidarity [28]. KOPABUGI established bylaws on common goals and members' responsibility, but set neither specific short- and long-term goals to achieve them nor plans for members' participation and role division. This eventually led to the absence of participation and cooperation, resulting in the failure of the cooperative.

The objectives of the KOPABUGI's establishment were in line with the needs of farmers. However, it seemed that there was not enough innovation to achieve that goal. Social innovation is the result of the exchange of knowledge, resources, and values between mobilized actors and is characterized by innovative forms of collaboration between individual actors [29]. This implies changes in attitudes, perceptions, and behaviors, resulting in new social practices that lead to social change [30]. KOPABUGI members failed to deviate from the existing inertia that passively followed the intervention and management of the aid agency and did not actively engage in the operations of cooperatives. The lack of experience and capacity of the KOPABUGI members was a direct cause of the lack of participation and cooperation, but the internal structure was also a closed system with limited flow of knowledge and values from inside and outside. Most of the decisions were made within the board of directors without taking into account various options, predicted results, or financial status. In searching the sales market of increased bananas, when it was judged that it was difficult to sign supply contracts with big buyers, the board members and members could have tried to find other ways to sell banana together, but they did not take an active action.

What role could the aid agency play in this process? The aid agency can be recognized as a participant with the common goal of sustainable development of KOPABUGI for collaboration, as well as an external knowledge or external resource that can drive innovation to cooperatives. Rasiah (2019) stated that the open innovation system has synergy in the transition from underdeveloped to developed state when four systems of "basic infrastructure, STI infrastructure, network cohesion, and global integration" are underpinned [12]. Due to the nature of foreign aid, aid agencies are bound by limited budget and time constraints, and within such constraints, they decide on the scale, means, and details of aid in order to effectively and efficiently produce outcomes that can contribute to the development of developing countries. Additionally, aid methods and support details should be useful from a long-term perspective while meeting the current needs of beneficiaries with the goal of sustainable development. In this sense, the aid agency could have assisted the fledgling cooperative KOPABUGI, which lacked human, financial, and physical resources, to build an independent foundation and an open innovation system by supporting education for capacity building, marketing for joint sales, and soft and hard infrastructure building.

The rice cooperative, which received continuous support from the aid agency for five years, has achieved increased production through the introduction of advanced farming methods and infrastructure building, and has secured sustainability through the improvement of cooperative management skill, the expansion of networks, and accumulation of cooperative funds. They had the opportunity to embrace external innovation through aid, and through this process, the system was built to enable self-reliance.

External support and capital for cooperative operation should be dealt with prudently in light of the basic principles of cooperatives, which are "autonomy and independence" and "self-reliance". However, in reality, new cooperatives in developing countries, particularly in rural areas, can hardly achieve financial stability and self-reliance without external assistance due to a lack of economic fundamentals and capabilities. If the aid agency had supported in marketing and sales, transportation, or vehicle costs instead of building a cooperative office, and provided continued education to the cooperative members to enhance their competence, would there be no difference in the current status of the banana cooperative? If aid resources are effectively allocated and support is provided based on rational strategies and principles, the outcome of aid can be sufficiently different. 
Based on research results and discussion, we would like to suggest which efforts and strategies should be undertaken by cooperative members and aid agencies for the successful development of cooperatives.

\section{Conclusions}

\subsection{Policy Proposal to Improve the Effectiveness of Aid}

\subsubsection{Aid Agency}

\section{Empowerment of the Cooperative}

As the case of the Banana cooperative shows, competence of the board and members are the key to a successful cooperative operation. When a cooperative is used for the ODA project as an effective and efficient means, the aid agency should provide it with continuous education and training so that the cooperative members can be cooperative on their own and have the capacity to make rational decisions. Especially for the poor in rural areas with low educational levels and minimal experience in operating economic organizations, the provision of education is of paramount importance. This capacity building should be done in a way that realizes diligence, self-reliance, and cooperation based on changes in the members' mindset.

Cooperative members need to understand the purpose and activities of the cooperatives and have specific training regarding their roles and responsibilities. In addition, board members need intensive training in the operation and financial management methods of cooperatives and planning, responsibilities, and the sense of ethics as board members.

\section{Consistent Support}

Temporary and unsystematic aid is criticized by international society. As the "big push theory" proposes that a "bit by bit" investment will not impact the process of growth, continued and substantial support of human and financial resources is required until the cooperative operation and capital are stabilized. KOPABUGI has not received any proper support or advice from the aid agency regarding the management of the cooperative since its establishment.

The establishment of a cooperative is only the first step toward self-reliance and never can be the result. Therefore, the aid agency should provide material and financial support until the cooperative reaches a certain level of financial stability and self-reliance. In addition, it should contribute to the formation of good governance through appropriate intervention and monitoring in the operational and decision-making processes of cooperatives and the transfer of know-how to cooperatives by support of specialized personnel.

\section{Systematic Support and Exit Strategy}

One of the adverse effects of aid is that when it is stopped, the beneficiaries' situation worsens due to their high dependence on it.

KOPABUGI's most needed support since the establishment was education for capacity building, marketing, and the transfer of experience to establish governance. However, without any analysis and consideration, the aid agency only provided support for the cooperative office building as requested by the cooperative, and this eventually led to the unfortunate consequence of KOPABUGI's decline. In addition, the termination of support and attention without any exit strategy that came unprepared for KOPABUGI at the end of the project period also drove the cooperative into a more difficult situation.

To minimize the negative effects caused by cutting support, it is critical to make a pragmatic action plan and implement a project from the long-term perspective. Within the limited budget and time period of the ODA project, the aid agency should develop the exit strategy from the planning stage, and the project should be implemented under a specific strategy so that the beneficiaries can achieve 
self-reliance and sustainability. In addition, a thorough analysis of the kind of support needed to achieve the goal of self-reliance and internal stability of cooperatives was required.

\subsubsection{Cooperative}

Clear Target Setting

The success of SMU, which was the main driving force behind rural development in the 1970s in South Korea, was based on the villagers' experience of succeeding in a small-scale project decided by themselves. For any small-scale project, success experience promotes confidence and will of the villagers, and has a great impact on mindset and behavior change. This can be realized by clear target setting and diligence for accomplishment. In the same context, new cooperatives should set clear, feasible, and measurable short-term goals that meet the purpose of the cooperative within their own capacity and focus on the cooperative's solidification. In the case of KOPABUGI, the purpose of establishment was clear and reasonable, but there were no detailed goals for the cooperative operation and no specific plans for the production, sale, and accumulation of the cooperative funds. If KOPABUGI had set specific and feasible targets, achieved them, and moved on to the next steps, then the participation of the members in economic activities would have been further activated. Based on this, even if a small amount of the cooperative's capital were formed, and if this capital were invested for the cooperative's growth, it might have been possible for KOPABUGI to achieve self-reliance through a virtuous cycle.

\section{Ownership}

Basically, a cooperative is an autonomous organization that is jointly-owned and democraticallycontrolled by its members [31]. Sense of ownership is the basis of cooperatives and an essential element for self-help and self-reliance. SDGs, a global agenda for poverty eradication, also stress the importance of a sense of ownership of the ODA recipient countries for the improvement of effectiveness of the ODA program. Sense of ownership is implemented in the form of cooperation and voluntary participation and can be strengthened by understanding the basic values, principles, and bylaws of cooperatives through education and training. Board members should encourage cooperative members to participate actively in the cooperative's economic activities and increase their contribution to cooperative funds as efforts to reduce aid dependency.

\section{Long-Term Goals}

ODA support cannot be permanent; therefore, a group of beneficiaries must plan from a long-term perspective while preparing for the end of the ODA. The medium- and long-term plans should be consistent with the purpose of the cooperative establishment and coordinated with the exit strategy of the aid agency. Cooperatives should establish a foundation for business diversification through the accumulation of funds, and management and acquisition of business management skills and related technique during the period of ODA support. All the steps taken by the cooperative should seek full self-reliance in cooperation with the aid agency. The ultimate goal of SMU is the well-being of individuals through income increase and community development. Cooperative operation should likewise improve the members' quality of life by income increase and achieve financial independence and autonomous decision-making through capacity building so that cooperatives can sustain without external support.

\subsubsection{Implication}

As a paradigm shift took place in international development cooperation from MDGs to SDGs, the importance of ownership and self-reliance in developing countries has been emphasized. In addition, various approaches to aid are being discussed as the sustainability of project outcome has emerged as a major agenda. In this context, cooperatives have been drawing attention as one of the driving tools 
for poverty eradication and economic development. Many developing countries, including Rwanda, are utilizing cooperatives as strategies and means for poverty reduction due to their characteristics, operational efficiency, and effectiveness, and many international aid agencies are also seeking to secure the sustainability of aid projects through the organization of cooperatives.

In Gihogwe village, Rwanda, where the SMU ODA program was implemented from 2011 to 2016, the "rice project", "livestock bank", and "improved banana plantation project" were launched and implemented as income increase projects. Consequently, two cooperatives were organized according to their own purpose and needs. The rice cooperative, CODARIKA, and the banana cooperative, KOPABUGI, differed greatly in the duration and scale of support received from the aid agency. Consequently, CODARIKA has been operating steadily even after the program ended, but KOPABUGI faced several crises and eventually collapsed.

Through a series of incidents of marketing failure, misconduct of the cooperative's president, and decision-making failure of the board of KOPABUGI, we can learn that the aid agency should provide comprehensive and all-round support such as giving advice on best practice; monitoring the cooperative's activities; and providing education, funding, and physical support in cooperative operation. The aid agency tries to organize cooperatives in community-level projects and use them as a means of self-reliance to enhance the effectiveness of aid; however, what is more important than the establishment of cooperatives is to strengthen the capacity of the members and stabilize the operation of the cooperative and, consequently, achieve self-reliance through systematic support. The success of cooperatives is possible through complementary efforts by both the aid agency and beneficiaries.

Appropriate monitoring and intervention by the aid agency can maximize the efficiency and effectiveness of the cooperative's governance and management. Establishment of exit strategies from the first stage of the project and the provision of continuous support based on analysis are necessary roles that the aid agency must play before and during the project implementation process. In addition, the cooperative should make efforts to strengthen its sense of ownership to achieve the long-term goal of self-reliance by setting clear and feasible cooperative short-term goals and achieving them one by one through cooperation among members, as in the success case of the SMU.

By comparing the two agricultural producers' cooperatives established in a village by the support of SMU ODA, this study proposed efforts the aid agencies and cooperatives should make to ensure effectiveness and sustainability of rural community development. There may be opposition to this proposal that the aid agencies should continue the support for cooperatives to the stabilization stage of cooperative operation, because the basic values of cooperatives emphasize "autonomy and independence" and "self-reliance by voluntary participation and sacrifice of cooperative's members but not by external support." It might be difficult to generalize the conclusion of this study, because it was drawn from the analysis of two cooperatives that were established in one village but showed opposite results. In addition, in the sense that various types of cooperatives exist in different environments and aid to cooperatives in developing countries also has been provided in various methods and approaches, this study, which draws conclusions through the analysis of one village case, has limitations.

However, as mentioned above, as it is difficult for newly established cooperatives to achieve growth without external support in the dire circumstances of developing countries, discussions on effective ways of supporting cooperatives to achieve self-reliance are essential. Moreover, at a time when aid agencies are increasingly trying to use cooperatives to promote economic growth in developing countries in order to improve aid effectiveness and reduce poverty, it is significant that this study proposed a strategy to ensure the success and sustainability of cooperatives based on comparative analysis of actual success and failure cases.

Author Contributions: Conceptualization: S.M. and S.-h.L.; methodology and formal analysis: S.M. and S.-h.L.; investigation and data curation: S.M.; writing-original draft preparation: S.M.; writing-review and editing: S.M. and S.-h.L.; supervision: S.-h.L. All authors have read and agreed to the published version of the manuscript.

Funding: This research received no external funding. 
Conflicts of Interest: The authors declare no conflict of interest.

\section{References}

1. Cristina, T.; De Souza Bermejo, P.H. Open social innovation. In Handbook of Research on Democratic Strategies and Citizen-Centered E-Government Services; Information Science Reference: Hershey PA, USA, 2014; pp. 144-163. [CrossRef]

2. ICA. What Is a Cooperative? Available online: https://www.ica.coop/en/cooperatives/what-is-a-cooperative (accessed on 11 October 2020).

3. Wanyama, F.O. Cooperatives and the Sustainable Development Goals: A contribution to the Post-2015 Development Debate; ILO: Geneva, Switzerland, 2014; Available online: https://www.ilo.org/wcmsp5/groups/public/---ed _emp/documents/publication/wcms_240640.pdf (accessed on 7 July 2020).

4. UN. Cooperatives in Social Development—Resolution Adopted by the General Assembly on 19 December 2017. 3p. Available online: https://base.socioeco.org/docs/a_res_72_143_e.pdf (accessed on 7 July 2020).

5. FAO. Agricultural Cooperatives Are Key to Reduce Hunger and Poverty. Available online: http://www.fao. org/news/story/en/item/93816/icode/ (accessed on 17 July 2020).

6. Marzuki, M.M.; Othman, R.; Aris, N.A.; Chik, W.M.Y.W.; Rahman, S.A. Sustainable Development Strategies for Cooperatives Sustainability. Available online: https://www.researchgate.net/publication/292681926_Susta inable_Development_Strategies_for_Cooperatives_Sustainability (accessed on 11 October 2020).

7. Mhembwe, S.; Dube, E. The role of cooperatives in sustaining the livelihoods of rural communities: The case of rural cooperatives in Shurugwi District, Zimbabwe. Jàmbá J. Disaster Risk Stud. 2017, 9, 1-9. [CrossRef] [PubMed]

8. FAO. Part One: Smallholders and Their Characteristics. Available online: http://www.fao.org/3/T0211E03.htm (accessed on 17 July 2020).

9. Brian, H.; Bruce, A. Unique Causes of New Cooperative Failure. Available online: https://cooperatives.exten sion.org/unique-causes-of-new-cooperative-failure (accessed on 17 July 2020).

10. Garnevska, E.; Liu, G.; Shadbolt, N.M. Factors for successful development of farmer cooperatives in Northwest China. IFAMR 2011, 14, 69-84. [CrossRef]

11. Braverman, A.; Guasch, J.L.; Huppi, M.; Pohlmeier, L. Promoting Rural Cooperatives in Developing Countries: The Case of Sub-Saharan Africa; The World Bank: Washington, DC, USA, 1991; ISBN 0-8213-1786-5.

12. Rasiah, R. Building networks to harness innovation synergies: Towards an Open systems approach to sustainable development. J. Open Innov. Technol. Mark. Complex. 2019, 5, 70. [CrossRef]

13. Chesbrough, H. Open innovation: A new paradigm for understanding industrial innovation. In Open Innovation: Researching a New Paradigm; Available online: https://myweb.rollins.edu/tlairson/ibtech/openinnovation.pdf (accessed on 12 October 2020).

14. Harrison, H.; Birks, M.; Franklin, R.; Mills, J. Case study research: Foundations and methodological orientations. In Proceedings of the Forum Qualitative Sozialforschung/Forum: Qualitative Social Research, Berlin, Germany, 2-4 March 2016.

15. Crowe, S.; Cresswell, K.; Robertson, A.; Huby, G.; Avery, A.; Sheikh, A. The case study approach. BMC Med Res. Methodol. 2011, 11, 100. [CrossRef] [PubMed]

16. WB. Country Profile|World Development Indicators, Rwanda. World Bank. Available online: https://databank.worldbank.org/views/reports/reportwidget.aspx?Report_Name=CountryProfile\&Id=b45 Ofd57\&tbar=y\&dd=y\&inf =n\&zm=n\&country=RWA (accessed on 18 October 2019).

17. RCA. Background. Available online: http://www.rca.gov.rw/about-rca/background/ (accessed on 18 October 2019).

18. Claude, M.N. Statistics on Cooperatives in Rwanda; Kigali. 2018. Available online: http://www.rca.gov.rw/media-center/news-archives/details/?tx_ttnews\%5Btt_news\%5D=171\&cHas $\mathrm{h}=7 \mathrm{c} 6752 \mathrm{~b} 06 f 74 b c 9 f c 2 f 80 \mathrm{abff1a56a68 \# .XzuUpugzbcc}$ (accessed on 18 October 2019).

19. Republic of Rwanda. National Policy on Cooperatives in Rwanda "Toward Private Cooperative Enterprises and Business Entities for Socio-Economic Transformation". Available online: http://www.rca.gov.rw/uploads/m edia/2019_03_20_Cooperative_Policy_ENGLISH._5_.pdf (accessed on 18 October 2019). 
20. Seong-jae, P.; Joon-kee, P.; Kie-yup, S. Operation of Agricultural Cooperatives for Rural Development. Available online: https://www.kdevelopedia.org/resource/view/04201210110122147.do\#.XzuaK-gzbcc (accessed on 3 March 2020).

21. Park, S. Analysis of saemaul undong: A Korean rural development programme in the 1970s. APDJ 2012, 16, 113-140. [CrossRef]

22. Mutesi, T. Increasing Banana Production and Productivity through Clean and High Yielding Seedlings. Available online: http://www.fao.org/rwanda/news/detail-events/en/c/1185123/ (accessed on 18 October 2019).

23. RCA. Who We Are. Available online: http://www.rca.gov.rw/about-rca/who-we-are/\#.XyjIsygzbcc (accessed on 18 October 2019).

24. Mellor, J.W. Measuring Cooperative Success: New Challenges and Opportunities in Low and Middle-Income Countries. Available online: https:/www.ocdc.coop/wp-content/uploads/2019/04/Metrics.pdf (accessed on 3 March 2020).

25. Staatz, J.M. Farmer Cooperative Theory: Recent Developments; No. 1502-2016-130749; U.S. Department of Agriculture, 1989. Available online: https://www.researchgate.net/profile/John_Staatz2/publication/4647151 2_Farmer_Cooperative_Theory_Recent_Developments/links/59a83457a6fdcc2398387321/Farmer-Cooperat ive-Theory-Recent-Developments.pdf (accessed on 7 October 2020).

26. Nkurunziza, B. Determining Rwanda's Comparative Advantage in Rice: Eastern Province Case Study. Master's Thesis, Stellenbosch University, Stellenbosch, South Africa, 2015.

27. Park, Y. [Fifty year history of Saemaul Undong] 6. Global Saemaul Undong project of North Gyeongsang Province (2). Kyongbuk Daily. 2 October 2019. Available online: https://www.kyongbuk.co.kr/news/articleVie w.html?idxno=2016667\&sc_sub_section_code=S2N109 (accessed on 18 October 2019).

28. Koo, J.; Baek, S.; Kim, S. The effect of personal value on CSV (Creating Shared Value). J. Open Innov. Technol. Mark. Complex. 2019, 5, 34. [CrossRef]

29. Chesbrough, H.; Di Minin, A. Open social innovation. New Front. Open Innov. 2014, 16, 301-315.

30. Cajaiba-Santana, G. Social innovation: Moving the field forward. A conceptual framework. Technol. Forecast. Soc. Chang. 2014, 82, 42-51. [CrossRef]

31. Rodgers, D. Guidance Notes to the Co-Operative Principles; International Co-operative Alliance: Brussels, Belgium, 2015; Available online: https://www.ica.coop/sites/default/files/publication-files/ica-guidance-notes-en-31062 9900.pdf (accessed on 5 October 2020).

Publisher's Note: MDPI stays neutral with regard to jurisdictional claims in published maps and institutional affiliations.

(C) 2020 by the authors. Licensee MDPI, Basel, Switzerland. This article is an open access article distributed under the terms and conditions of the Creative Commons Attribution (CC BY) license (http://creativecommons.org/licenses/by/4.0/). 